\title{
An Exploratory Study of Motivational Factors on Women Entrepreneurship Venturing in Malaysia
}

\author{
Hasni Che Ismail \\ College of Law, Government \& International Studies \\ Universiti Utara Malaysia, 06010 Sintok, Kedah, Malaysia \\ E-mail: has1121@uum.edu.my
}

Faridahwati Mohd. Shamsudin

Othman Yeop Abdullah Graduate School of Business

Universiti Utara Malaysia, 06010 Sintok, Kedah, Malaysia

E-mail: faridah@uum.edu.my

\author{
Mohammed S. Chowdhury (Corresponding author) \\ Othman yeop Abdullah Graduate School of Business College of Business \\ Universiti Utara Malaysia, 06010 Sintok, Kedah, Malaysia \\ E-mail: mchowdr@yahoo.com or m.chowdhury@uum.edu.my
}

Received: December 20, 2011 Accepted: January 9, 2012

doi:10.5296/ber.v2i1.1434 URL: http://dx.doi.org/10.5296/ber.v2i1.1434

\begin{abstract}
This study explored the effects of motivational factors on women entrepreneurship venturing in Malaysia. The research was conducted on 80 entrepreneurs through random sampling technique. All hypotheses were tested using regression analysis and Pearson correlations, controlling for demographic variables of gender, age, and education, years of experience, and start-up funding. While the results of this study found significant effect of pull motivational factors, there is a marginal effect of push motivational factors on women entrepreneurship venturing in Malaysia. Implications and a number of recommendations are discussed.
\end{abstract}

Keywords: Women entrepreneurship, Pull motivation, Push motivation, Venturing, Malaysia 


\section{Introduction}

Nearly one billion people are living on less than US\$1 a day, an estimated 70 percent of whom are girls and women (UNDP, 2008). One way to alleviate poverty is to empower women economically, especially through projects that encourage women to engage themselves in entrepreneurial income generating activities (Chowdhury and Amin, 2011). An entrepreneur is someone who innovates and whose function is to carry out new combinations called "enterprises" and are the prime movers in economic development (Schumpeter, 1934). Women entrepreneurs have enormous potential to bring prosperity in the world and therefore encouraging women entrepreneurship is very important (McConnell, 2007). These women entrepreneurs are generally classified into self-entrepreneurs, inheritance entrepreneurs, and partner entrepreneurs (Starr andYudkin, 1996).

The last half-century has witnessed monumental changes for women as income earners (Smith-Hunter, 2006). Many developed and developing countries are taking steps to promote women entrepreneurships among their people. In Malaysia, empowering women project was undertaken in partnership with the Ministry of Entrepreneur and Co-operative Development (MECD) and the Malay Chamber of Commerce (MCCM), aimed at empowering women by creating greater awareness of micro-finance and various small loans available to low-income women, and through skills and training program (UNDP, 2008). Malaysian government's target to create 4,000 women entrepreneurs among the hardcore poor with a household monthly income of less than RM 440by 2012 (Jalil, 2010), reflects an urgent need for the development of women entrepreneurship in the micro and small enterprises in the region. These women entrepreneurs are active in a large number of enterprises and make a substantial contribution to national economies (United Nations, 2006); and more so for Malaysian economy because of its increasing number of women-owned businesses in the past three decades (Teo and Chong, 2007).

Despite the growing importance of women entrepreneurship in creating job opportunities of millions of people and government's efforts to create, develop quality, resilient and successful entrepreneurship, and to cultivate an enterprising culture among women, little is known about the motivation of these Malaysian women becoming entrepreneurs. Previous research (for example Birds, 1988) has revealed that entrepreneurial intentions to start a business and the decisions that occur before the start-up shape the subsequent goals, strategies, and structure of the new business. Since a business will neither start up nor succeed (Robertson et al., 2003), it has become important to improve our understanding of the motivational factors associated with the new venture creation in a country like Malaysia where the government has been very concerned to promote, nurture and cultivate enterprising culture among Malaysian women. Lack of empirical research is still evident in Malaysia. The current study aims to fill this gap. Its purpose is to explore the motivational factors of women entrepreneurs as these factors bear substantial influence on their willingness to venturing into business. 


\subsection{Theoretical Framework and Hypotheses}

The literature on motivational factors to women entrepreneurship development in developing countries like Nepal, India, Sri Lanka and Malaysia is very sparse. Even where it exists, a proper analysis of the motivational factors is missing. Behavioral psychologists define motivation as the psychological process that gives behavior purpose and direction (Kreitner, 1995). For this paper, we operationally define motivation as entrepreneurial internal stimulation characterized as pull or push factors based on different personal position, nature and desire. In line with this definition we present the following theoretical framework, as depicted in Figure 1.

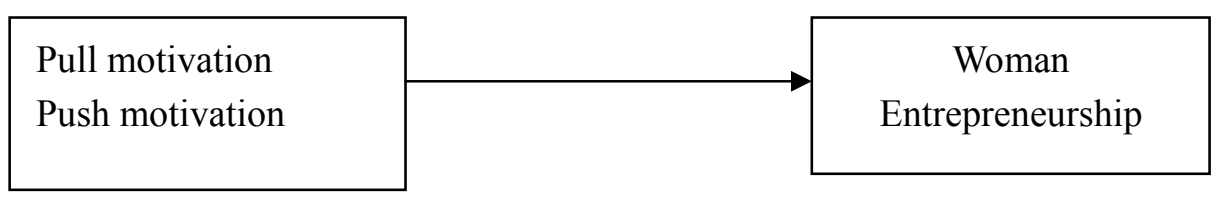

Figure 1. Theoretical Framework

The theory is that, the decision to become self-employed may stem from both pull and push effects. It posits that the intention of carrying out a given behavior may be affected by several factors such as needs, values, wants, habits, and beliefs. Birds (1988) and Hughes $(2003,2006)$ have documented these factors that affect the intention of carrying out a given behavior.

Based on the above theoretical framework, we proposed the following hypotheses:

Hypothesis 1: There is a significant relationship between pull factors of intrinsic motivation and women's willingness to venture creation in Malaysia.

Hypothesis 2: There is a significant relationship between push factors of extrinsic motivation and women's willingness to venture creation in Malaysia.

\section{Review of Literature}

Push factors are those factors that relate to necessities such as (1) unemployment, (2) redundancy, (3) recession, (4) inadequate family income, (5) dissatisfaction with current job, and (6) the need to accommodate work and home roles. The decision to become self-employed that stem from the pull effects induced by a thriving economy producing entrepreneurial opportunities relate to such factors as (1) need for independence, (2) need for a challenge, (3) improved financial opportunity, (4) self-fulfillment, (5) desire to be own boss, (6) flexibility for balancing family and work, (7) potential to develop a hobby, (8) personal achievement (to be reckoned in the society), and (9) role models and other people's influence (friends and family).

There is no dearth of relevant literatures for supporting our theoretical framework and hypotheses regarding these push and pull factors of motivation to women entrepreneurs. For instance, several studies (Alstete, 2003; Carter et al., 2003; Eckel and Grossman, 
2002; Georgellis and Wall, 2004; Gosh andCheruvalath, 2007; Hughes, 2006; Kirkwood, 2009; Malonand Cohen, 2001; McClelland et al., 2005; Segal et al., 2005; Wang et al., 2004; Wilson et al., 2004) have documented that women are motivated by both pull and push factors.

In Malaysia, psychological motives such as self-satisfaction, the search for independence, and source of finance have been found to be motivational factors for women entrepreneurs to start-up business (Nordin, 2005). In general, Benzing and Hung (2009) and Segalet al. (2005) have found pull factors to be more prevalent than push factors. Amit and Muller (1995) have found that entrepreneurs who experienced push motivations are less successful (financially) than those built upon pull factors. It is important to note that women may be lured into entrepreneurship by their continuing lack of progress within the workplace. This glass ceiling may be pushing women into entrepreneurship (McClellandet al., 2005; Winn, 2004).

Motivation is a significant factor in the start-up and success of the business. Behavioral psychologists point out that individual job performance is a function of ability and motivation and motivation originates from both internal and external stimulations. The motivations caused by push and pull factors, as stated earlier in this paper, stimulate the potential entrepreneur's expectations. It is the motivation that gives rise to entrepreneurial decisions directly. Push and pull motivational factors determine personal entrepreneurial behavior, stimulate a person's expectations, and create the existence of entrepreneurial need, resulting in the formulation of entrepreneurial motivation. Thus there appears to be a need to identify motivational factors of women entrepreneurs that give rise to their decision to start a business. Women, in Malaysia, are becoming a very important economic group and therefore more efforts are needed to nurture them in taking up entrepreneurship.

The motivation of women entrepreneurs in Malaysia has become an important area of recent policy and academic debate. Little rigorous and in-depth research, however, has been undertaken on the issues of women entrepreneurs' motivation toward their willingness to new venture creation, especially in developing countries like Malaysia. This paper, therefore, intends to address the motivational factors of women entrepreneurs and their relationship to the willingness to venture creation by women entrepreneurs.

\section{Methodology}

\subsection{Survey instrument}

A survey instrument was developed to capture the information relating to the research objectives. A structured questionnaire was prepared in English and translated into the Malay language, which is the national language of Malaysia, for the purpose of interviewing women entrepreneurs in the northern part of the country. Questionnaires were delivered by hand by one of the researchers to the women-owned micro and small businesses. Information was gathered regarding the biographical information of the participating women entrepreneurs and motivational factors for starting their businesses. The questionnaire included tested items from earlier research (Birley, 1989; Birley and Westhead, 1994; Gatewood et al., 1995) on motivation and start-ups. The resulting questionnaire comprised three sections. The first 
section comprised a set of nine items to measure intrinsic (pull) motivation to venture creation. A five point-Likertscale anchored by "strongly agree" to "strongly disagree"was applied to measure success. A typical item was: "I need to become independent." Chronbach's alpha of the items was .68. The second part consisted of seven items to measure push (extrinsic) factors considered to be responsible for the creation of the business. One typical item was: "I do not have job." Chronbach's alpha was .70. The third section had five items to measure intention to venture creation. A typical item was: "I am determined to start a business in the near future." Chronbach's alpha was .69. The last part related to collecting biographical information of the respondents.

\subsubsection{Sample and data collection}

To achieve the objectives of this study a sample of 80 entrepreneurs was chosen randomly. The study included a survey of 80 entrepreneurs to investigate into factors that motivate them to become an entrepreneur. The study was conducted in the northern part of Kedah, one of the fourteen states in Malaysia, i.e. in Sintok. Sintok was chosen since it is gaining its importance as a commercial hub because of its location at the heart of UUM bordering Thailand and its close proximity to Langkawi, the legendary island of Malaysia. This region, therefore, is in favorable position for building entrepreneurs in its traditional and non-traditional foods, herbal products, fruits, motels, etc. The target population of this study was micro and small women owned business in Sintok.

\section{Data Analysis}

Data collected was statistically analyzed using SPSS. Data analysis followed a correlation design. The purpose of correlation design is to investigate the extent to which variations in one factor correspond with variations in one or more factors based on correlation coefficients (Isaac \& Michael cited in Chowdhury, 2007). The coefficient of correlation measure was used to examine the relationship between the intention to venture and independent variables (push and pull factors of motivation). Hypotheses testing were done to analyze the direct effects of independent variables on women intention to become entrepreneurs, controlling for demographic variables. For demographic variables, frequency tables were used for the purpose of analysis.

Regression Model

$Y=\partial+\beta^{1} \chi^{1}+\beta^{2} \chi^{2}+\varepsilon$

$\mathrm{Y}=$ dependent variable (entrepreneurship intention)

$\partial=$ constant

$\beta^{1}=$ beta coefficient for independent variable pull motivation variable

$\chi^{1}=$ pull motivation

$\beta^{2}=$ beta coefficient for push motivation

$\chi^{2}=$ push motivation variable 


\section{Macrothink}

$\varepsilon=$ error term

\section{Findings and Analysis}

\subsection{Demographic factors of women}

Biographical information of women entrepreneurs of the participating owned business was obtained including their age group classification, marital status, experience, and highest academic qualifications (see Table 1).

Table 1. Demographic factors of women entrepreneurs

\begin{tabular}{|l|c|c|}
\hline \multicolumn{1}{|c|}{ Demographic factors } & No. & Percentage \\
\hline Age: & 32 & 40 \\
$25-35$ & 25 & 31 \\
$36-45$ & 19 & 24 \\
$46-55$ & 4 & 5 \\
$56-65$ & & \\
\hline Education: & 3 & 4 \\
Masters & 24 & 30 \\
Degree & 33 & 41 \\
Diploma & 12 & 15 \\
Certificate & 8 & 10 \\
SPM/STPM & & 70 \\
\hline Work experience: & 56 & 30 \\
\hline Yes & 24 & 45 \\
No & & 26 \\
\hline Marital status: & 36 & 10 \\
Married & 21 & 6 \\
Unmarried & 8 & 13 \\
Divorced & 5 & \\
Widowed & 10 & 26 \\
Not indicated & & \\
\hline
\end{tabular}

Table 1 indicates that majority women entrepreneurs are relatively experienced, educated, and young. Most of them are well educated as $71 \%$ of them are degree and diploma holders. One might argue that educated people are generally creative and innovative and look for something unique to fill a need or want. The educated and experienced women are more interested in becoming entrepreneurs than non-educated and inexperienced women (Kavita et al., 2008). Most women are in the age of 25 and 45, and support the contention that the people between the age of 25 and 45 are most likely to be involved in entrepreneurial activity (Reynolds et al., 2002). 


\section{Macrothink}

Table 2. Results of the structure of the participating family business

\begin{tabular}{|l|c|c|}
\hline \multicolumn{1}{|c|}{ Business structure variables } & No. & Percentage \\
\hline Business size (number of employees): & & 26 \\
Myself & 21 & 34 \\
Between 2 to 4 & 27 & 24 \\
Between 5 to 10 & 19 & 10 \\
Between 11 to 25 & 8 & 6 \\
Between 26 to 50 & 5 & \\
\hline Industry: & & 62 \\
Retail & 50 & 15 \\
Whole sale & 12 & 4 \\
Services & 3 & 10 \\
Food & 8 & 5 \\
Agriculture & 4 & 4 \\
Herbal product & 3 & 89 \\
\hline Legal status: & & 11 \\
\hline Sole proprietorship & 71 & \\
Partnership & 9 & \\
\hline
\end{tabular}

$71 \%$ of the women-owned business that participated in this study are sole proprietors $(89 \%)$, and are operating in retail trade $(62 \%)$ with few engaged in other sectors like food, services, agriculture etc. (see Table 2).

Table 3. Results regarding the business start-up information

\begin{tabular}{|l|c|c|}
\hline \multicolumn{1}{|c|}{ Business start-up information variables } & No. & Percentage \\
\hline Start-up funding & & 75 \\
Personal savings & 60 & 15 \\
Relatives and friends & 12 & 10 \\
Bank loan & 8 & \\
\hline Path to business ownership: & 52 & 65 \\
Founder & 25 & 31 \\
Purchased & 03 & 4 \\
Inherited family business & & 13 \\
Experience before self-employment: & 10 & 62 \\
Unemployed & 50 & 22 \\
Self-employed & 18 & 3 \\
Worker & 2 & \\
Supervisor & & \\
\hline
\end{tabular}

The result from Table 3 shows that participating women-owned businesses were founded by the current owner-manager (65\%) and used personal savings (75\%) as start-up funding. 


\subsubsection{Correlation and regression analysis}

Table 4 presents correlation coefficients and other descriptive statistics for all variables assessed in this study and inter-correlations among the variables.

Table 4. Descriptive statistics and inter-correlations among all variables

\begin{tabular}{|l|c|c|c|c|c|}
\hline & $\begin{array}{c}\text { Pull } \\
\text { motivation }\end{array}$ & $\begin{array}{c}\text { Push } \\
\text { motivation }\end{array}$ & Intention & Mean & $\begin{array}{c}\text { Standard } \\
\text { deviation }\end{array}$ \\
\hline Pull motivation & 1 & $0.230^{*}$ & $0.484^{* *}$ & 34.52 & 13.68 \\
\hline Push motivation & & 1 & $0.278^{*}$ & 30.60 & 2.59 \\
\hline Intention & & & 1 & 22.52 & 5.36 \\
\hline
\end{tabular}

${ }^{*}$ Correlation is significant at the 0.05 level (2 tailed)

**Correlation is significant at the 0.01 level ( 2 tailed)

Table 4 indicates that while both pull $(\mathrm{r}=0.484)$ and push $(\mathrm{r}=0.278)$ motivation are positively correlated with women entrepreneurial intention, pull factors of motivation posit a stronger correlation with entrepreneurial intention than push factors of motivation.

Regression analysis was then employed to examine the relationship between two independent variables (see Table 5) and entrepreneurial intention. This was aimed at determining the highest influence factor toward entrepreneurial intention and also at testing the study model. The results are summarized in Table 5.

Table 5. Coefficients of determination between independent variables and dependent variable

\begin{tabular}{|l|c|c|c|}
\hline \multicolumn{1}{|c|}{ Variable } & $\begin{array}{c}\text { Beta } \\
\text { standard coefficient }\end{array}$ & T value & Significance \\
\hline Intention & & 9.665 & 0.000 \\
\hline Pull motivation & 0.615 & 5.498 & 0.000 \\
\hline Push motivation & 0.065 & 0.579 & 0.565 \\
\hline $\begin{array}{l}\text { Model summary: } \\
\text { Adjusted R-square 33.5\% }\end{array}$ & & & \\
F=15.839 & & & \\
Significance .000 & & & \\
\hline
\end{tabular}

As can be seen in Table 5, pull motivation $(\mathrm{p}<0.05)$ affected intention in a positive direction, and has more influence on women intention to become entrepreneurs, as evidenced by the highest $\mathrm{T}$ and Beta score (see Table 5) and push factors of motivation are not statistically significant ( $>0.05$ ). Adjusted R-square for this model is 0.335 , which indicates that $33.5 \%$ of the changes in the dependent are explained by the independent variables. Altogether independent variables explained $33.5 \%$ of the variation.

\section{Discussion and Implications}

One fundamental argument underlying the framework of this study is the dimension of pull and push factors of motivation that evolved around the women entrepreneurship studies. The 
study clearly support hypothesis 1. Majority of Malaysian women entrepreneurs in Sintok region are drawn to entrepreneurship by "pull factors" such as the need for independence, challenge, to be recognized by the society, the urge to try to do something on their own etc. This is in conformity with many studies. For example, Benzing and Hung (2009), Hisrichand O'Brien (1981), and Segalet al. (2005) found pull factors to be more prevalent than push factors of motivation.

Interestingly this study found a low strength of relationship of push factors of motivation toward entrepreneurial intention and the relationship was not found to be statistically significant. This suggests that motivating force is not directly related to material needs and is in consistent with the findings of Hisrich and Brush (1986). Overall, the results of this study confirm the findings of several of previous studies (for example, Gosh andCheruvalath, 2007; Heilman and Chen, 2003; Smith-Hunter, 2006).

\subsection{Implications}

One implication of this study is that motivation is a key to the start-up and success of the business. One must be strongly motivated by non-financial need and must have strong desire and interest to lead his or her business. In other words, self-engagement is an essential element in setting-up and guiding the business to meeting its objectives.

Another implication is that education is an essential element for entrepreneurship development. The educated generation is more interested in becoming entrepreneurs. Therefore, in line with social learning theory, the parents must be encouraged to motivate their children, particularly daughters to venture into entrepreneurship.

In addition, collection of data on the motives of Malaysian women entrepreneurs are needed in order to allow the policy makers, educators, women associations and the public to identify appropriate planning of national policies and programs for women entrepreneurship development. Furthermore, Malaysian women entrepreneurs must have an understanding of the entrepreneurial orientations that include confidence, courage, strong will power, risk taking, creativity, innovativeness and so forth. All these can be embedded within the women entrepreneurs through short courses on motivation. This is where the government can be instrumental in nurturing the motivational skills within the women entrepreneurs by giving them incentives required for the start-up of business.

In conclusion, this study contributes to both theoretical and practical aspects of motivational factors affecting the start-up of businesses by women entrepreneurs. It appears that a better understanding of the important factors influencing the start-up of businesses by women entrepreneurs will have implications for Malaysian women entrepreneurs to broaden their businesses successfully in this globalised environment.

\section{Limitations of the Study}

The limitation of the study is that the study assessed only motivational aspects concerning women entrepreneurship in a relatively little sample. Although motivators found in this study are consistent with previous research studies, it is important to have a large number of 
entrepreneurs to improve the robustness of findings. More comprehensive research is still needed to gain more insights into the motivational factors for self-employment of women entrepreneurs. Another limitation is that the study concentrated in only one small city, though in its growing phase.

\section{Future Research Directions}

This study considers entrepreneurs in one city. Further research can be undertaken to include a region comprising many cities. It is also recommended that the findings of this study be validated with a large-scale randomly selected target population. It is also interesting to compare between men and women entrepreneurs using comprehensive framework developed. Another area that needs to be undertaken is the study of influence of exogenous variables such as outside assistance and government policy on venture creation. Comparison between nations is another area that warrants further research.

\section{References}

Alstete, W. (2002). On becoming an entrepreneur: an evolving topology, International Journal of Entrepreneurship Behaviour and Research, 8 (4), 222-234. http://dx.doi.org/10.1108/13552550210436521

Amit, R. \& Muller, E. (1995). Push and pull entrepreneurship, Journal of Small Business \& Entrepreneurship, 12 (4), 64-80.

Benzing, C. \& Hung, C. (2009). A comparison of the motivation of small business owners in Africa, Journal of Small Business and Entrepreneurship Development, 16 (1), 60-77. http://dx.doi.org/10.1108/14626000910932881

Birds, B. (1988). Implementing entrepreneurial ideas: The case for intention, Academy of Management Review, 13 (3), 442-453.

Birley, S. (1989). Female entrepreneurs: are they different?'Journal of Small Business Management, 27 (1), 32-37.

Birley, S. \& Westhead, P. (1994). A taxonomy of business start-up reasons and their impact on firm's growth and size, Journal of Business Venturing, 9 (1), 7-31. http://dx.doi.org/10.1016/0883-9026(94)90024-8

Carter, N., Gartner, W., Shaver, K. \& Gatewood, E. (2003). The career reasons of nascent entrepreneurs, Journal of Business Venturing, 18(1), 13-19. http://dx.doi.org/10.1016/S0883-9026(02)00078-2

Chowdhury, M. (2007). Overcoming entrepreneurship development constraints, Journal of Enterprising Communities, 1(3), 240-251. http://dx.doi.org/10.1108/17506200710779549

Chowdhury, M. \& Amin, M. (2011). The effects of human, social and financial capital on women entrepreneurs in Bangladesh and their willingness to venture creation, International Journal of Business and Economic Perspectives, 6 (1), 138-149. 
Eckel, C. \& Grossman, P. (2002). Sex differences and statistical stereotyping in attitudes toward financial risk, Evolution and Human Behavior, 23(4), 281-295. http://dx.doi.org/10.1016/S1090-5138(02)00097-1

Gatewood, J., Shaver, G. \& Gartner, W. (1995). A longitudinal study of cognitive factors influencing start-up behaviors and success at venture creation, Journal of Business Venturing, 10, 371-391. http://dx.doi.org/10.1016/0883-9026(95)00035-7

Georgellis, Y. \& Wall, H. (2004). Gender differences in self-employment [online]. Working paper, The Federal Reserve Bank, St. Louis. http://research.stlousfed.org/wp/1999008.pdf. http://research.stlousfed.org/wp/1999008.pdf.

Gosh, P. \& Cheruvalath, R. (2007). Indian female entrepreneurs as catalysts for economic growth and development, The International Journal of Entrepreneurship and Innovation, 8 (2), 139-148. http://dx.doi.org/10.5367/000000007780808048

Heilman, E. \& Chen, J. (2003). Entrepreneurship as a solution: the allure of self employment for women and minorities, Human Resource Management Review, 13 (2), 347-364.

Hisrich, R. \& O’Brien, M. (1981). The women entrepreneur as a reflection of the type of business, in Vesper K. H. (Ed.), Frontiers of Entrepreneurship Research, Wellesley, MA, Babson College, 54-67.

Hisrich, D. \& Brush, C. (1986). Characteristics of the minority entrepreneurs, Journal of Small Business Management, 24, 1-8.

Hughes, K. (2006). Exploring motivation and success among Canadian women entrepreneurs, Journal of Small Business Entrepreneurship, 19 (2), 117-120.

Hughes, K. (2003). Pushed or pulled? Women's entry into self-employment and small business ownership, Gender, Work and Organization, 10 (4), 433-54. http://dx.doi.org/10.1111/1468-0432.00205

Jalil, S. (2010). Four thousands entrepreneurs to be created from the hard core poor, Bernama, 17 March, 2010. www.bernama.com.

Kavita, R., Anantharaman, N. \& Jaysingam, S. (2008). Motivation factors affecting entrepreneurial decision: a comparison between Malaysian women entrepreneurs and women non-entrepreneur,' Communications of the IBIMA, 2 (12), 85-89.

Kirkwood, J. (2009). Motivational factors in a push-pull theory of entrepreneurship, Gender in Management: An International Journal, 24 (5), 346-354. http://dx.doi.org/10.1108/17542410910968805

Kreitner, R. (1995) Management, 6th ed., Boston: Houghton Mifflin.

Malon, M. \& Cohen, L. (2001). Time for a change? Women's accounts of the move from organizational careers to self-employment, British Journal of Management, 12(3), 217-230. http://dx.doi.org/10.1111/1467-8551.00195 
McClelland, M., Swail, J., Bell, J. \& Ibbotson, P. (2005). Following the pathway of female entrepreneurs: a six-country investigation, International Journal of Entrepreneurship Behavior and Research, 11 (2), 1-28.

McConnell, L. (2007). New initiative focuses on opportunities for women: doing business report [Online]. http://doingbusiness.org.

Nordin, M. (2005). Women business: determinants for venturing in Malaysian SMEs. http://www.epu.jpm.my/english.

Reynolds, D., Bygrave, D., Autio, E., Cox, W. \& Hay, M. (2002). Global entrepreneurship monitor: executive report: Babson College and Ewing Marion Kaufman Foundation. httpp://www.gemconsortium.org.

Robertson, M. Collins, A., Madeira, N. \& Slater, J. (2003). Barriers to start-up and their effect on aspirant entrepreneurs, Education \& Training, 45 (6), 308-316. http://dx.doi.org/10.1108/00400910310495950

Schumpeter, A. (1934). The Theory of Economic Development: An Inquiry of Profits, Capital, Credit, Interest and the Business Cycle, Cambridge, Massachusetts, Harvard University Press.

Segal, G., Borgia, D. and Schoenfeld, J. (2005). The motivation to become an entrepreneur, International Journal of Entrepreneurship Behavior and Research, 11 (1), 42-57. http://dx.doi.org/10.1108/13552550510580834

Smith-Hunter, A. (2006). Women entrepreneurs across racial lines, UK, Edward Edgar Publishing.

Starr, J. \& Yudkin, M. (1996). Women Entrepreneurs: A Review of Current Research, Wellesley, MA, Center for Research on Women.

Teo, W. and Chong, C. (2007). Theorizing a framework for factors influencing performance of women entrepreneurs in Malaysia, Journal of Asia Entrepreneurship\& Sustainability, 3 (2), 2-17.

United Nations (2006). Entrepreneurship and e-business development for women-ESCAP (Economic Council for Asia and the Pacific). http://www.unescap.org/idd/pubs/st_escap.pdf.

UNDP (United Nations Development Program), Malaysia (2008). Nurturing women entrepreneurs. http//:www.undp.org.my.

Wang, Y., Waltkins, D., Harris, N. \& Spicer, K. (2004). The relation between succession issues and business performance: evidence from UK family SMEs, International Journal of Entrepreneurship Behavior and Research, $10 \quad$ (1/2), 59-84. http://dx.doi.org/10.1108/13552550410521380

Wilson, F., Martino, D. \& Kichul, J. (2004). Our entrepreneurial future: examining gender and ethnic identity, Journal of Developmental Entrepreneurship, 9 (3), 177-197. 


\section{Macrothink}

Business and Economic Research

ISSN 2162-4860 2012, Vol. 2, No. 1

Winn, J. (2004). Entrepreneurship: not an easy path to top management for women, Women in Management Review, 19 (3), 143-153. http://dx.doi.org/10.1108/09649420410529852

\section{Copyright Disclaimer}

Copyright reserved by the author(s).

This article is an open-access article distributed under the terms and conditions of the Creative Commons Attribution license (http://creativecommons.org/licenses/by/3.0/). 